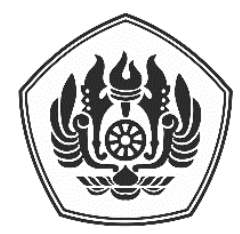

\author{
Padjadjaran Journal of International Law \\ ISSN: 2549-2152, EISSN: 2549-1296 \\ Volume 4, Number 2, June 2020
}

\title{
The Use of Methods or Means of Warfare Which Caused Damage to the Natural Environment Based on the International Humanitarian Law
}

\author{
Muhammad Ryan Dwi Saputra*
}

\begin{abstract}
Environment has been widely recognized as international interest and all states shall avoid any activities that may damage the environment. The adoption of Stockholm Declaration 1972, World Charter for Nature 1982, and Rio Declaration 1992 denotes that protection of the environment reflects customary international law. War or armed conflict was one of the principal contributors to the environmental damages. As in the Vietnam War, the United States attempted to create artificial rain by seeding the cloud which led to the establishment of the 1976 Convention on the Prohibition of Military or Any Hostile Use of Environmental Modification Techniques (ENMOD Convention) and the Additional Protocol I 1977. However, the Gulf War 1990-1991 gave rise to the questions whether those two instruments were sufficient to encompass the environmental damages caused by the Iraqi methods of warfare by burning oil wells and spilling oil to the sea. This issue was raised by the author since these two instruments set a high threshold and unclear terms on a degree of environmental damages to be considered as a violation. Accordingly, this paper discusses whether the environmental damages caused by the Persian Gulf War meets the threshold set by the Additional Protocol I and the ENMOD Convention, and further discusses the international responsibility that arose from the damages caused by the War. The result of this research shows that environmental damages caused by Iraqi burning oil wells and oil spill apparently did not satisfy the threshold set by the Additional Protocol I and the ENMOD Convention.
\end{abstract}

Keywords: Armed Conflict, Environment, Gulf War, International Humanitarian Law, Responsibility

\section{Penggunaan Metode Berperang yang Berakibat Kerusakan Terhadap Lingkungan Berdasarkan Hukum Humaniter Internasional}

\begin{abstract}
Abstrak
Lingkungan sudah diakui sebagai permasalahan internasional dan semua negara wajib untuk menghindari kegiatan yang berakibat kerusakan terhadap lingkungan. Pembentukan Deklarasi Stockholm 1972, Piagam Dunia Untuk Lingkungan 1982 dan Deklarasi Rio 1992 menunjukkan bahwa perlindungan terhadap lingkungan telah merefleksikan hukum kebiasaan internasional. Perang atau konflik bersenjata merupakan salah satu penyebab utama kerusakan lingkungan. Seperti percobaan untuk membuat hujan buatan yang dilakukan oleh Amerika Serikat dalam Perang Vietnam yang berujung dibentuknya Convention on the Prohibition of Military or Any Hostile Use of Environmental Modification Techniques 1976 (Konvensi ENMOD) dan Protokol Tambahan I 1977. Namun, Perang Teluk 1990-1991 menimbulkan pertanyaan apakah kedua instrumen tersebut dapat mencakup kerusakan lingkungan yang diakibatkan oleh metode berperang Irak dengan membakar dan menumpahkan minyak. Permasalahan tersebut diangkat oleh penulis karena kedua instrumen tersebut menetapkan kriteria kerusakan lingkungan yang
\end{abstract}

PADJADJARAN JOURNAL OF INTERNATIONAL LAW Volume 4 Issue 2 Year 2020 [ISSN 2549-2152] [e-ISSN 2549-1296] Senior Associate at IABF Law Firm, Intiland Tower, JI. Jend. Sudirman Kav. 32, Jakarta, ryandwsputra@gmail.com. 
kurang jelas dan standar yang terlalu tinggi untuk dinyatakan sebagai pelanggaran. Oleh karena itu, penelitian ini akan membahas apakah kerusakan lingkungan yang diakibatkan oleh Perang Teluk memenuhi syarat yang ditetapkan oleh Protokol Tambahan I dan Konvensi ENMOD, dan juga membahas tanggung jawab internasional yang timbul sebagai akibat dari kerusakan lingkungan yang diakibatkan oleh perang. Hasil penelitian menunjukkan bahwa kerusakan lingkungan yang diakibatkan oleh Irak dengan membakar dan menumpahkan minyak ternyata tidak memenuhi standar yang ditetapkan oleh Protokol Tambahan I dan Konvensi ENMOD.

Kata kunci: Hukum Humaniter Internasional, Konflik Bersenjata, Lingkungan, Perang Teluk, Pertanggungjawaban

\section{A. INTRODUCTION}

Humans and the environment need each other to survive. Humans take advantage of natural resources and other potentials found in the environment to live. Likewise, the environment needs human protection to maintain its natural resources. The importance of the environment has also been universally recognized.

Unfortunately, environment protection continues to be ignored in situations of war. Throughout history, environments have been victims of armed conflict. The military, to gain an advantage over their opponents, often burnt fields, sprayed large amounts of chemicals into forests, destroyed dams and embankments, and poisoned water sources. An attack even has to manipulate natural resources and use nature as a weapon to achieve the objectives of war strategy. Environmental destruction, depletion of natural resources, death of flora and fauna are always ignored. ${ }^{1}$

Environmental damage from war activities is inevitable. The recovery process is time-consuming and requires a lot of money. Indeed, humanitarian law instruments exist to prevent the disproportionate impact of armed conflict. However, with the increasing potential for destroying modern weapons and combat strategies, it is beginning to appear that current provisions of humanitarian law do not fully address the dangers that armed conflict poses to the environment. ${ }^{2}$ The dangers that can result from war on the environment are an apparent reason for a stronger framework of humanitarian law to prevent and protect the environment from worse occurrences in the future.

In general, protection of the environment can be found in two branches of international law, namely international environmental law and international humanitarian law. International environmental law includes some provisions regarding liability and potential redress for environmental damage, but does not specify whether such provisions apply in times of peace or armed conflict. The provisions in humanitarian law differ from the customary international law due to the environmental damage standards that must be met, as contained in the Protocol Additional to the Geneva Conventions of August 12, 1949 and Relating to the Protection of Victims of International Armed Conflicts (Additional Protocol 1$)^{3}$ and the Convention on the Prohibition of Military or Any Other Hostile Use of Environmental Modification Techniques (ENMOD Convention). ${ }^{4}$

Additional Protocol $I$ is one of humanitarian law instruments that limits the ways and methods of warfare to not

\footnotetext{
U. C. Jha, Armed Conflict and Environmental Damage, New Delhi: Vij Books India Pvt Ltd, 2014, p.1. 
Environment Based on the International Humanitarian Law

cause excessive damage to the environment. These regulations are contained in Articles 35 (3) and 55 (1) of Additional Protocol I, which prohibit the method or means of warfare which cause widespread; long-term; and severe damage to the natural environment. In addition, the ENMOD Convention specifically deals with the use of environment as a weapon or means of warfare. The formation of this convention was encouraged by the United States' (US) action using herbicides as a weapon to deforest and create artificial rain during the Vietnam War. The same provision can be found in Article 1 (1) of the ENMOD Convention which stipulates that the threshold of 'widespread, long-lasting or severe' damage must meet.

Although the provisions of Additional Protocol I and the ENMOD Convention were in place, this did not automatically prevent or even reduce the environmental damage that resulted from war. The main reason is that the environmental damage standards that have been provided are too high, making them difficult to meet.

This is relevant when it comes to the 1990-1991 Persian Gulf War, in which Iraq deliberately spilled large amounts of oil into the Persian Gulf. This action was followed by the burning of more than 600 Kuwaitiowned oil refineries, which caused massive smoke and covered a large area causing atmospheric pollution for a long time in Kuwait. The amount of oil spilled by Iraq is estimated at around 11 million barrels, almost the largest-ever oil spill. Damage also occurred to coastal swamps, wildlife (more than 15,000 dead birds), coastal vegetation, fisheries, and offshore oil operations.

Although more than two decades have passed, the Gulf War is the most environmentally destructive war in modern history. Some people have called the Gulf War the "Hyper War". In 43 days of intense

William M. Arkin (et.al), On Impact Modern Warfare and the Environment: A Case Study of the Gulf War, A Greenpeace Study Prepared for a "Fifth Geneva" fighting, the war has resulted in more Iraqi deaths than in the cumulative 8-year IranIraq war. The effects include unprecedented environmental devastation; the most efficient assassination operation ever undertaken by any military, one of the largest displacement of civilians in the shortest time; worst oil fire; and is one of the largest oil spills in history. ${ }^{5}$

Interpretive difficulty in Additional Protocol $I$ and the ENMOD Convention raises the question of whether the environmental damage resulting from the Gulf War meets the criteria for environmental damage in humanitarian law. In fact, these two legal instruments are the only legal basis that can respond to concerns caused by war on the environment.

Seeing the significance of the Gulf War case, the author seeks to analyze the implementation of the humanitarian laws in this case. The paper also further examines whether the provisions in Protocol I and the ENMOD Convention reflect customary international law, and whether the oil spill and oil fires meet the standards set by the two international humanitarian law instruments or not. Given that Iraq and the US were not participating countries in Additional Protocol I and the ENMOD Convention during the Gulf War, it is crucial to know these two legal instruments' binding force. On the other hand, as a violation of a right and the non-fulfillment of an international obligation create responsibility, it is essential to see what form of responsibility will arise from the offense.

Convention on the Protection of the Environment in Time of Armed Conflict, London: Greenpeace, 1991, p. 5. 
B. THE GULF WAR: ONE OF THE WORST MAN-MADE ENVIRONMENTAL DISASTER IN HISTORY

1. The Onset of War: Coalition Attacks and Destruction by Oil

This war was triggered by the Iraqi invasion on August 2, 1990 of Kuwait, ${ }^{6}$ followed by occupations to obtain Kuwait's abundant oil reserves. ${ }^{7}$ Previously, Saddam Hussein accused Kuwait of withdrawing its shares from the Rumaila oil field on the Iraq-Kuwait border, and that Kuwait had lowered oil prices by exceeding their production quotas. With the United Nations' approval, this war occurred by involving a conflict between Iraq and 34 coalition countries under the leadership of the US to expel Iraqi forces from Kuwait and restore the ousted Emir's government. ${ }^{8}$ This war can be divided into three main stages: Iraq Invasion, Operation Desert Shield, and Operation Desert Storm.

\section{a. Iraqi Invasion}

The invasion of Iraq took place on August 2, 1990, two hours past midnight. Iraq carried out this invasion by deploying about 100,000 Saddam Hussein's troops through southern Iraq towards Kuwait. This number is in stark contrast to the Kuwaiti armed forces which only consist of 16,000 soldiers. ${ }^{9}$ The uneven number and power of weapons made Iraq succeed in conquering Kuwait. ${ }^{10}$ Iraq installed an interim government to replace the Kuwaiti government. Six days later, Kuwait

The Editors of Encyclop/Edia Britannica, Loc.Cit.

Ibid.

The Editors of Encyclop/Edia Britannica, Persian Gulf War 1990-1991, 2015,

http://www.britannica.com/event/Persian-Gulf-War, accessed on $22^{\text {nd }}$ of April 2016.

9 Earle Rice Jr., Overview of the Persian Gulf War, 1990, Newark: Mitchell Lane Publishers, 2009, p. 7.

Ibid.

11 See Security Council Resolution No. 660, August $2^{\text {nd }}$, 1990. was annexed by Iraq as their 19th province. The United Nations responded by issuing Security Council Resolution No. 660 which condemned the invasion and ordered Iraq to withdraw from Kuwait. ${ }^{11}$

\section{Operation Desert Shield}

This operation began on August 7, 1990 with the deployment of US troops in Saudi Arabia. The deployment was in response to requests for military assistance from King Fahd, the leader of Saudi Arabia, to protect its oil fields. ${ }^{12}$ This concern is caused if Iraq attacks Saudi Arabia, then Iraq will have control over its oil fields and control the majority of the world's oil reserves (Kuwait, Saudi Arabia, and Iraq). ${ }^{13}$ Upon this request, President George H. W. Bush ordered US troops' total deployment to Saudi Arabia. ${ }^{14}$

On November 8, 1990, President Bush confirmed that he was ready to attack. ${ }^{15}$ UN Security Council Resolution No. 678 allowed member states to use all means necessary to enforce the previous resolution if Iraq did not leave Kuwait on January 15, $1991 .{ }^{16}$ One week before that deadline, with the US and coalition troops piling up in the Gulf region, President Bush finally secures a Joint Resolution of Congress authorizing the use of armed force against Iraq. ${ }^{17}$

\section{Operation Desert Storm}

Two days after deadline given by the UN, US and coalition forces ${ }^{18}$ launched airstrikes that destroyed Iraqi civilian

Laurence A. French \& Lidija Nikolic-Novakovic, War Trauma and its Aftermath: An International Perspective on the Balkan and Gulf Wars, Lanham: University Press of America, 2012, p. 57.

13 Ibid.

14 Brian Callanan and David Weiler, Op.Cit., p. 5.

15 Ibid.

16 See Paragraph $1 \& 2$ of Security Council Resolution No. 678 , November 29 1990.

17 Brian Callanan and David Weiler, Op.Cit., pp. 6-7.

18 The total coalition troop range is about 700,000 people; about 500,000 of them are US troops. See 
and military infrastructure that lasted from January 17 to February 24, 1991. ${ }^{19}$ These airstrikes also killed a large number of Iraqi troops. The US and coalition ground offensives began on February 24 and lasted only 100 hours. ${ }^{20}$ Iraqi troops immediately withdrew and returned to Iraq via a four-lane highway and were bombarded by US warplanes. This incident became known by the media as the "highway of death". ${ }^{21}$ The US proposed a truce for February 27, 1991. By February 28 , the coalition had ultimately defeated Iraqi forces and cessation of war was declared. Ceasefire negotiations began on March 1 , and on March 17, the first wave of a US withdrawal began. The ceasefire finally entered into force on April 11, 1991, five days earlier, Iraq had withdrawn its troops from Kuwait. ${ }^{22}$

During the war, Iraqi forces used Kuwaiti-owned oil production facilities to damage the environment to thwart the efforts of coalition forces. By burning mines and oil refineries and spilling millions of crude oil barrels into the Persian Gulf, the Iraqi military has created what has been described as the 'worst man-made environmental disaster in history'. ${ }^{23}$

Before the war, Saddam Hussein had threatened to spill Kuwaiti oil into the sea if coalition forces tried to expel

"Persian Gulf War", A+E Networks, 2009, http://www.history.com/topics/persian-gulf-war, (accessed on 23 April 2016). See also Gulf War Fast Facts, CNN Library, 2015, http://edition.cnn.com/2013/09/15/world/meast/gul f-war-fast-facts/, (accessed on 23 April 2016).

19 Brian Callanan and David Weiler, Op.Cit. p. 7.

20 Ibid.

21 Rodney P. Carlisle, Persian Gulf War, New York: Infobase Publishing, 2003, p. 101

22 Brian Callanan \& David Weiler, Loc.Cit.

23 Katherine M. Kelly, Op.Cit., pp. 923-924.

24 Karen Hulme, "Armed Conflict, Wanton Ecological Devastation and Scorched Earth Policies:How the 1990-91 Gulf Conflict Revealed the Inadequacies of the Current Laws to Ensure Effective Protection and Preservation of the Natural Environment", Journal of Conflict and Security Law, Vol. 2, No. 1, 1997, p. 47.

25 Peter Rowe, Op.Cit., p. 14
Iraqi troops from Kuwait. ${ }^{24}$ Not long after the desert storm operation took place, on January 22, 1991 Iraqi forces deliberately set fire to oil storage facilities and tanks in Kuwait and began to spill crude oil from the Sea Island oil terminal at Mina al-Ahmadi into the Gulf. $^{25}$ On January 29, 1991, Iraq continued pumping oil into the sea from Mina al-Bakr in Iraq, exacerbating the already existing oil spill in the Gulf. ${ }^{26}$ The source of the oil spill also comes from the oil storage area in al-Khafji, which started releasing oil around January $22-23,1991$. It is estimated that the total volume of the oil spill is close to 2.5-3 million barrels and could reach 4 million barrels, as the first or second worst oil spill in history. ${ }^{27}$ By May 1991, the damage had exceeded $400 \mathrm{~km}$ from Saudi Arabia's coast and Kuwait's southern coast. ${ }^{28}$

As it was not enough, Iraq exacerbated this by burning the oil. At the time of the August 1990 invasion, Iraq was preparing to destroy Kuwait's oil infrastructure. ${ }^{29}$ When the desert storm operation began on January 17, 1991, the first arson took place where Iraqi artillery burned an oil storage tank in al-Khafji, Saudi Arabia. ${ }^{30}$ The burning continued at the Kuwaiti oil field and storage facility at al-Wafrah, ${ }^{31}$ two Kuwaiti refineries or oil storage tanks at al-Shuaiba and Mina Abdullah. ${ }^{32}$ By the

$26 \quad$ lbid

27 There are several different sources regarding the amount of the oil spill. The New York Times reports that seven tankers spilled oil, but only six can be accounted for; See Matthew Wald, "After the War: Gulf Oil Spill Vexing Cleanup Efforts", The New York Times, $\quad 7$ April 1991, http://www.nytimes.com/1991/04/07/world/afterthe-war-gulf-oil-spill-vexing-cleanup-efforts.html, accessed on $24^{\text {th }}$ of April 2016.

28 Ibid.

29 William M. Arkin (et.al), Op.Cit., p. 66

Peter Rowe, Op.Cit., p. 14.

Ibid.

Beyond Broadcast Curriculum Guide, "Timeline", n.d, https://www.pbs.org/wgbh/pages/frontline/teach/gu Ifguide/gwtimeline.html, accessed on $11^{\text {th }}$ of June 2016. 
end of the month, it was reported that approximately 60 wells had been blasted. These fires are reported to have resulted in 15,000 square kilometers of smoke. ${ }^{33}$

4. The Environmental Damage to the Persian Gulf

The Middle East is the third most prosperous region in natural oil resources in the world. The Persian Gulf is an almost entirely closed sea area, approximately 615 miles long and from 35 miles to 210 miles wide in a given area. $^{34}$ The International Union for Conservation of Nature and Natural Resources (IUCN) states that the Persian Gulf's natural resources are vital for the Gulf region's prosperity and development, most importantly freshwater, which coastal desalination plants mainly produce. ${ }^{35}$ It comes as no surprise that the damage resulting from the Gulf War to the environment and to the desalination plant caused harm to everyone in the Persian Gulf region. ${ }^{36}$

In the aftermath of the Gulf War, studies did show that the coral reefs in early 1992 appeared to be in good condition. The impact of the war on parts of the intertidal and subtidal areas of the sea also did not show any significant damaging effects, especially since these two areas also often become polluted in peacetime. ${ }^{37}$ Meanwhile, the fishing industry shows few direct impacts ascribed to the 1991 oil spill. About half of the oil spill has evaporated, 1 million barrels have been returned, 2-3 million barrels were stranded, mainly in Saudi Arabia. ${ }^{38}$

William M. Arkin (et.al), Loc.Cit.

Graham Evans, Persian Gulf, Encyclopædia Britannica, 2016, http://www.britannica.com/place/Persian-Gulf, accessed on $11^{\text {th }}$ of June 2016.

William M. Arkin (et.al), Op.Cit., p. 65

Abdullah Toukan, Loc.Cit.

A. R. G. Price (et.al), The 1991 Gulf War: Environmental Assessment of IUCN and Collaborators, Gland: IUCN, 1994, p. 3; Green Cross International, Op.Cit., p. 66.

38 Chris Poonian, Op.Cit., p. 30.

$39 \quad$ Ibid.
Marine life and other natural resources are heavily affected by war. The Persian Gulf's wildlife, including fish, seabirds, dolphins, certain breeds of turtles, and dugongs are threatened with extinction because they are considered highly vulnerable to changing environmental conditions. ${ }^{39}$ The oil also did affect seaweed as the most productive subtidal habitat, and has long-term consequences for commercial fisheries and food sources in the Gulf. The reason is, around 10,000 Bahrainis make commercial fishing their source of life. ${ }^{40}$ The fisheries in this region are also a multimillion dollar industry, and traditional fishing is a source of social progress. ${ }^{41}$

In the Persian Gulf surroundings' environment, burning Kuwait's wells and oil refineries have two effects on the environment around the Gulf: atmospheric pollution and possibly climate change. ${ }^{42}$ The review team estimated that the heat released from these massive fires was about 86 billion watts, the equivalent of 200,000 hectares of forest fires. The fire caused a cloud of smoke stretching more than $1000 \mathrm{~km}$ to blanket Kuwait, Qatar, Bahrain, the United Arab Emirates, and parts of Iraq, Iran, Oman, and Yemen. ${ }^{43}$

The smoke from oil fires is rapidly affecting respiratory disease among the Kuwaiti population, primarily affecting the elderly and young children. ${ }^{44}$ Black rain was reported in Turkey and all of Iran, as well as in Bulgaria, the southern Soviet Union, Afghanistan, and Pakistan, and black snow in Kashmir in March $1991 .{ }^{45}$ Within $200 \mathrm{~km}$ of the oil

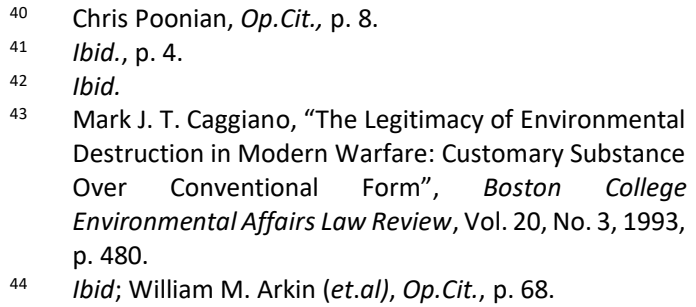


fires, sooty clouds covered the sun and caused a $10 \%$ drop in land temperatures that darkens Kuwait even during the day. The oil that falls on the desert's surface creates lakes and rivers, and therefore becomes a dead trap for birds who think of it as water. In other places, the forests began to die. ${ }^{46}$

Furthermore, the battlefield of the Gulf War itself has become an environmental disaster area. Remnants of modern warfare such as artillery, shells containing depleted uranium (a poisonous and radioactive substance) were left buried in the desert, and groundwater became scarce due to contamination. More than one million landmines remain buried in the Kuwaiti desert and the Persian Gulf's sea area. ${ }^{47}$

\section{IRAQI METHODS OF WAR ACCORDING TO INTERNATIONAL ENVIRONMENTAL AND HUMANITARIAN LAWS}

There are two aspects of protection that can address environmental protection as a warfare method within the international law framework: environmental protection which is used as a means or weapon; and the general protection of the environment itself. 48

The state's obligation not to cause environmental damage to other countries is generally contained in Principle 21 of the Stockholm Declaration and Principle 2 of the Rio Declaration which states "the obligation of states to ensure that any activity within their jurisdiction or control does not cause environmental damage to

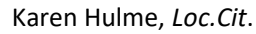
Conference on the Human Environment Stockholm, 16 June 1972 (A/CONF.48/14 and Corr.1) (Stockholm Declaration); Rio Declaration on Environment and Development Rio de Janeiro, 14 June 1992 (A/CONF.151/26/Vol.I).

50 Gunther Handl, Declaration of the United Nations Conference on the Human Environment (Stockholm Declaration) 1972, and the Rio Declaration on other countries". ${ }^{49}$ In addition, Principle 23 of the Rio Declaration also requires states to protect the environment under their occupation. In the Stockholm Declaration and Rio Declaration, there is a provision that these two instruments had reflected customary international law at the time of their adoption. ${ }^{50}$ This is relevant in the Iraqi action case because by the time the oil was spilled and burned, Kuwait had been occupied and annexed by Iraq to become the 19th province. ${ }^{51}$ The environmental damage caused by this action has spread to other countries. It even covers Bahrain, ${ }^{52}$ which is hundreds of kilometers away, so it is clear that Iraq's actions have violated these provisions.

Meanwhile, from the international humanitarian law standpoint, according to Article 23 (g) of the Hague Regulations, the destruction of enemy property can only be permitted if it is necessary for the war. ${ }^{53}$ Article 53 of Geneva Convention IV also prohibits the destruction of public and private property by an occupying power, unless the destruction is truly necessary for the purposes of military operations. ${ }^{54}$ Furthermore, Article 147 stipulates the destruction of large property which is not justified by military interests and carried out illegally and arbitrarily (wantonly), is categorized as a grave breach. ${ }^{55}$

In 1992, the UN General Assembly adopted non-voting Resolution No. 47/37 on 'Protection of the Environment in Times of Armed Conflict', which states that destruction of the environment which is not justified by military interests and is carried out arbitrarily is clearly against international

Environment and Development, 1992, United Nations Audiovisual Library of International Law, 2012, p. 3.

51 Anthony H. Cordesman, Kuwait: Recovery And Security After The Gulf War, Colorado: Westview Press, 1997, p. 11.

52 William M. Arkin (et.al), Op.Cit., p. 64

53 Article 23 (g) of Hague Convention (IV) Respecting the Laws and Customs of War on Land, 18 October 1907.

54 Article 53 of Geneva Convention Relative to the Protection of Civilian Persons in Time of War (Fourth Geneva Convention), 12 August 1949, 75 UNTS 287 (Geneva Convention IV).

55 Article 147 of the Geneva Convention IV. 
law. In its Advisory Opinion on Nuclear Weapons, the ICJ quotes this sentence. ${ }^{56}$ The ICJ notes that the UN General Assembly Resolution is non-binding, but adds that it can provide important evidence to establish the existence of a rule or the emergence of an opinio juris. ${ }^{57}$ The prohibition against environmental damage or destruction that is not justified by military interests and is carried out arbitrarily (unwarranted), is repeated in Article 44 of the 1995 San Remo Manual. ${ }^{58}$ This is an accurate reflection of current customary international law.

In the Gulf War case, although an oil well could be considered a military object, it must be proven that the attack provides a definite military advantage. However, considering that the oil well that Iraq burned was located in an occupied country (Kuwait), the destruction of the oil well would not affect the outcome of the war and offered no definite military advantage at the time. ${ }^{59}$ The only military advantage Iraq might have is that the build-up of thick smoke can obscure their army from the air forces' view of the coalition forces. However, this move has little effect on military operations. ${ }^{60}$

Even if the oil well was a military object in the prevailing circumstances, and there was a little military advantage from the smoke reducing visibility, Iraqi action's legality would depend on applying the principle of proportionality. Massive air pollution across Kuwait is equivalent to excessive damage to the environment and the civilian population, thus contradicting this principle.

In addition, before retreating from Kuwait, Iraqi troops set fire to oil wells and blew up buildings, including the parliament

ICJ Reports, Op.Cit., p. 242.

Ibid., p. 254-255.

See Article 44 of the 1995 San Remo Manual; Louise Doswald-Beck, San Remo Manual on International Law Applicable to Armed Conflicts at Sea, Cambridge University Press, Cambridge, 1995.

59 Jonathan P. Edwards, The Iraqi Oil "Weapon" in the 1991 Gulf War: an International Law Analysis, Monterrey: Naval PostGraduate School, 1992, p. 78. building and the Kuwait National Museum. In conclusion, Iraqi action of burning and spilling oil in Kuwait appears to have been motivated not by military considerations, but by mere revenge. ${ }^{61}$ In the absence of military considerations, Iraqi actions constituted a violation of the general application of the humanitarian law norms.

\section{LEGAL STATUS AND IMPLEMENTATION OF ADDITIONAL PROTOCOL I AND THE ENMOD CONVENTION ON IRAQI METHODS OF WAR IN THE GULF WAR}

1. The Legal Status of Additional Protocol $I$ and the ENMOD Convention as Customary International Law

The use of methods and means of war that results in environmental damage is regulated in Article 35 (3) and Article 55 (1) Additional Protocol I 1977. Meanwhile, the use of the environment as a weapon or means of war which results in environmental damages is regulated in the 1976 ENMOD Convention.

In the Gulf War case, there was no precedent for accepting Articles 35 (3) and 55 (1) of Additional Protocol I as customary international law, unlike those in Additional Protocol I which have been recognized by several countries participating in the writing of the text. To be considered an international custom, a rule must fulfill the two elements: a custom that is general in nature, ${ }^{62}$ and that practice must be accepted as law. ${ }^{63}$ This element is often referred to as state practice and opinio juris sive necessitatis, respectively. ${ }^{64}$ These elements must be

Leslie C. Green, The Environment and the Law of Conventional Warfare, Canadian Yearbook of International Law, Vol. 29, 1992, p. 222.

61 Hilaire McCoubrey \& Nigel D. White, International Law of Armed Conflict, Aldershot: Dartmouth Publishing Co. Ltd., 1992, p. 369.

62 J. G. Starke, Pengantar Hukum Internasional, Jakarta: Sinar Grafika, 2006, p. 178

63 Malcolm N. Shaw, Op.Cit., p. 84.

64 Ibid., p. 46 
fulfilled cumulatively to be considered a source of international law based on Article 38 (1) (b) of the ICJ Statute.

Several countries such as Germany and the US clearly stated that the Article was a new rule that had never existed in previous treaties and the state practices before 1977 did not support the formation of this regulation. ${ }^{65}$ These are explicit rejections from the states of the existence of this Article as customary international law.

Iraq itself is not a party to Additional Protocol $\mathrm{I}$ and only a signatory party to the ENMOD Convention. Looking at its ratification, Protocol I was ratified by 99 countries on 15 November 1990, the ENMOD Convention by 71 countries on 31 December 1990. However, it is still difficult to conclude that there were practices before the Gulf War that would indicate the law to obtain a customary international law status, ${ }^{66}$ and there is no visible international legal expert to say that the ENMOD Convention is customary law. ${ }^{67}$

From the practice, these two instruments are not included in the Iraqi military manual, state statements, and other actions indicating that Iraq accepts these rules. Meanwhile, Iraq, the US, and Kuwait which have interests are also not participating countries and do not have supporting practices to make it as customary law. This shows that the ICJ's conditions in the North Sea Continental Shelf cases that the practice must involve countries whose interests are affected are also not fulfilled.

After the Gulf War, Iraq, in a letter to the UN Secretary General in 1991, said not to exploit the environment and

65 Andru E. Wall, Legal and Ethical Lessons of NATO's Kosovo Campaign, Newport: Naval War College Press, 2002, p. 349

66 Karen Hulme, War Torn Environment: Interpreting the Legal Threshold, Leiden: Martinus Nijhoff Publishers, 1750, p. 104. natural resources as weapons. Likewise, the US in its response to the ICRC Memorandum stated that American practice does not involve war methods that result in widespread, long-term and severe environmental damage. Several countries have included these rules in the military manual and submitted to the ICJ in the Nuclear Weapons Case and Nuclear Weapons (WHO) Case 1996 that they consider Articles 35 (3) and Article 55 (1) to be customary international law. The new rules were adopted in the Guidelines on the Protection of the Environment in Times of Armed Conflict in 1994 and the Rome Statute as war crimes in 1998.

Neither instrument can be said to be customary international law before and during the Gulf War. On the other hand, both instruments represent a new application or operational manifestation of humanitarian law principles, which are needed because of the development of technology and methods of warfare. To avoid this method of warfare, a prohibition from international law is required to restrict the use of weapons in war. The most appropriate opinion to describe the status of the two regulations in 1990 is to reflect 'emerging norms of international law'.

2. Application of Additional Protocol I and the ENMOD Convention in the Gulf War

In order to make Additional Protocol I relevant in an international case, it must be an international armed conflict. The fact that Iraq was then the occupying power of Kuwait and the US' coalition forces came to withdraw Iraqi troops from Kuwait shows that the Gulf War

67 Ronald St. John MacDonald, Marine Pollution and Spoliation of Natural Resources as War Measures: a Note on Some International Law Problems in the Gulf War, Boston: Martinus Nijhoff Publishers, 1994 p. 294. 
fulfilled the criteria for international armed conflict as stipulated in Article 2 of the concurrent provisions of the 1949 Geneva Conventions.

In this protocol, environmental issues have been discussed twice, namely in Article 35 (3) and Article 55

(1) which reads respectively:

"It is prohibited to employ
methods or means of
warfare which are
intended, or may be
expected, to cause
widespread, long-term
and severe damage to the
natural environment."
"1. Care shall be taken in
warfare to protect the
natural environment
against widespread, long-
term and severe damage.
This protection includes a
prohibition of the use of
methods or means of
warfare which are
intended or may be
expected to cause such
damage to the natural
environment and thereby
to prejudice the health or
survival of the
population."

Article 55 specifies a broader prohibition against environmental damage. ${ }^{68}$ The two articles look similar, but Article 55 (1) contains provisions that the environmental damage must cause harm to human safety and health. Such harm to human safety and health is not considered a condition for the application of the prohibition to result in environmental damage, but as the most important category contained within the broader limitations of the prohibition. ${ }^{69} \quad$ Meanwhile, the prohibition contained in Article 35 (3) which incorporates the section dealing with means and methods of war in the Protocol, shows that the civilian population is not the only one protected.

Subsequently, the ENMOD Convention prohibits states from engaging in the use of environmental modification techniques. Article 1 (1) of the ENMOD Convention states:

"Each State Party to this

Convention undertakes

not to engage in military or any other hostile use of environmental modification techniques having widespread, longlasting or severe effects as the means of destruction, damage or injury to any other State."

Article 2 defines environmental modification techniques (environmental modification techniques) as follow:

"The environmental modification techniques covered are those intended to change 'through the deliberate manipulation of natural processes, the dynamics, composition or structure of the Earth'".

Environmental modification techniques include techniques intended to change the movement, composition or structure of the earth by manipulating natural processes. However, not all use of environmental modification techniques is prohibited. When viewed from Article 1 and Article 2 , several conditions must be met, namely: ${ }^{70}$

a. only military use or other hostile acts of environmental 
modification techniques are prohibited, whether offensive or defensive;

b. The prohibited act must consist of manipulation of natural processes. Natural processes are instruments manipulated as weapons;

c. the prohibited act must be deliberate;

d. the action must have widespread, long-lasting or severe consequences;

e. the act must result in destruction, damage or loss; and

f. the destruction, damage or loss must be inflicted on other ENMOD Convention parties, both countries at war and neutral countries.

The two instruments were made for different purposes and there is no overlap in substance. In its scope of application, Additional Protocol $\mathrm{I}$ is narrower than the ENMOD Convention. Although Additional Protocol I does not distinguish between enemy territory and warring party territory resulting in environmental damage, this instrument applies only to international armed conflicts. The ENMOD Convention applies to all situations where environmental modification techniques are used intentionally for military or hostile purposes resulting in losses to other countries. The wording of the ENMOD Convention means encompassing environmental modification techniques in noninternational armed conflicts.

Both Additional Protocol I and the ENMOD Convention apply in every case of environmental damage or destruction. Limitation criteria are set in both instruments, and they both use the same adjective: 'widespread', 'long

71 Ibid, p. 190

72 Understandings of the Enmod Convention, Report of the Conference of the Committee on Disarmament, Volume I, General Assembly Official records: Thirty-first session, term (or long-lasting)', and 'severe'. The similarity between these two does not mean the same, for the following reasons:

i. In the ENMOD Convention, the three terms are stated alternatively ('widespread, longlasting or severe effects'), while in Additional Protocol I it is written cumulatively ('widespread, longterm and severe'). So that in the ENMOD Convention, one fulfillment of the criteria is sufficient, but in Additional Protocol I three criteria must be met. Because environmental damage often fulfills one or even two of these criteria but not the third, the Protocol sets too high a limit. ${ }^{71}$

ii. The three criteria regulate the coverage of the affected area, duration and degree of damage. However Protocol I and the ENMOD Convention have different meanings. In the ENMOD Convention, 'widespread' covers an area on a scale of several hundred square kilometers; "Long-lasting" means over a period of several months or about a season; 'Severe' involves serious or significant disturbance or harm to human life, natural and economic resources or other assets. ${ }^{72}$ The first two criteria are defined in quantitative terms so that, quite clearly, the third criterion has an ambiguous meaning. Whereas in the Protocols, widespread 'refers to an area whose area may be less than several hundred square kilometers; ${ }^{73}$ 'Long-term' refers to a decade, ${ }^{74}$ and; 'Severe' includes damage which could

Supplement No. 27 (A/31/27), New York, United Nations, 1976, pp. 91-92.

73 Yoram Dinstein, Op.Cit., p. 191.

74 Jean Pictet (et.al) Op.Cit., p. 416. 
jeopardize the survival of the civilian population or that would pose a risk to natural resources and health problems. ${ }^{75}$ However, it is not possible to calculate the potential duration of environmental damage that will be caused in advance.

If these two regulations are applied to Iraqi oil's burning and spilling, there will be difficulties in meeting the criteria. Additional Protocol I requires that the requirements for environmental damage, namely 'widespread, long-term and severe' must be met cumulatively, which become the main problem. ${ }^{76}$

The 'widespread' element in Additional Protocol I requires that environmental damage covers a minimum of 100 square kilometers. Greenpeace reported that the oil spill covered up to $400-650 \mathrm{~km} 2$ as far as Bahrain, and by May 1991, the damage had reached $400 \mathrm{~km}$ from the coast of Saudi Arabia and the southern coast of Kuwait. The oil well fires caused a cloud of smoke stretching more than $1000 \mathrm{~km}$ to blanket Kuwait, Qatar, Bahrain, the United Arab Emirates, and parts of Iraq, Iran, Oman, and Yemen. ${ }^{77}$ Within 200 $\mathrm{km}$ of the oil fires, sooty clouds covered the sun and had caused a 10\% drop in temperature which caused birds and forests to die. ${ }^{78}$ From this fact, the element of 'widespread' has been fulfilled.

The 'severe' element requires that the damage can endanger human health, natural resources, and the economy. The smoke from oil fires is rapidly affecting respiratory disease among the Kuwaiti population, mainly affecting the elderly and young

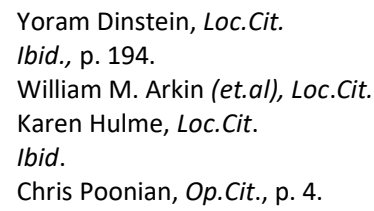

children. ${ }^{79}$ The oil spill poses a toxic hazard to drinking water sources in the Gulf and Kuwait, polluting the Persian Gulf marine ecosystem. ${ }^{80}$ A $10 \%$ decrease in fisheries' catch affected the Kuwaiti economy in 1991-1992, because fishing activities were stopped after the war. ${ }^{81}$ Moreover, in the Bahrain fishery, a loss of US $\$ 3.35$ million was estimated due to the war. In addition, human health is also threatened due to fishery products contaminated by poisons due to oil spills. ${ }^{82}$ From 1991-1992, the Kuwaiti oil company suffered heavy losses in production due to the destruction of oil wells. The costs for cleaning up the oil spill amounted to USD 700 million. ${ }^{83}$ Based on the facts above, the 'severe' element has been fulfilled.

The problem lies in the fulfillment of the 'long-term' element. The environmental damage from fires and oil spills did not last for 10 years, as required by the element. One year after the war, the Persian Gulf marine ecosystem looks healthy and the oil has mostly evaporated or been successfully recovered. ${ }^{84}$ Studies have shown that the oil content in the Persian Gulf marine ecosystem was reduced by 1993. ${ }^{85}$ Kuwaiti fishery catches proved unchanged until seven years after the war. Regarding the impact of the oil fires, they did not result in large-scale contamination of the Gulf region for a long time. ${ }^{86}$ Thus, the 'long-term' element was not met because the environmental damage caused by Iraq did not last for a decade.

The circumstances may be different when it comes to the ENMOD Convention. Although it is not required to be met cumulatively, all three criteria

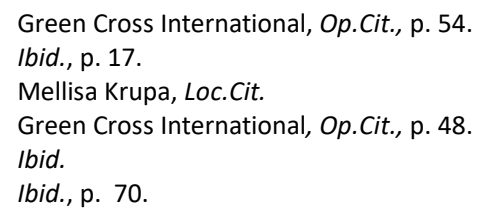


for 'widespread, long-lasting or severe effects' have been met, given that the long-lasting limit is only measured in months or seasons. In addition, based on the understanding of Article 2 of the ENMOD Convention, environmental modification techniques include changes in weather patterns, which of course occur in Kuwait.

The relatively conventional methods used by Iraq are by no means outside the scope of applying the ENMOD Convention. Moreover, burning oil wells is included in Article 2 which says 'any techniques'. However, the element of 'deliberate manipulation of natural processes' is not fulfilled. By burning the oil well, Saddam Hussein had no intention of causing a change in the atmosphere's movement. ${ }^{87}$ As Yoram Dinstein put it: ${ }^{88}$

"The rationale is that the direct cause of the environmental destruction was the detonation of the explosives on the well-heads, and the fact that those wellheads have been constantly supplied with inflammable oil to feed the fire triggered by those explosions by virtue of the pressures in the strata below them is a secondary, not a causative, matter. Explosives, not oil pressure, were manipulated".

The environmental damage was a direct result of the detonation of the bomb in the eye of the oil well, not from the use of oil as a weapon to change natural processes. Since there is no manipulation of natural processes, these elements are not fulfilled. Regarding the oil spill, Saddam Hussein could have intended to destroy the enemy by polluting the Persian Gulf waters, causing the closure of Saudi Arabia's desalination plant. ${ }^{89}$

The ENMOD Convention can be applied in situations in the Gulf War when countries view burning oil wells and spilling oil as using a natural part of the environment, namely crude oil, for military purposes. However, this is not a general interpretation of the situation in the Gulf War. The prevailing view is that Iraq was using man-made oil wells, not natural crude oil as a weapon, which is outside the scope of the ENMOD Convention. ${ }^{90}$ Manipulation of natural processes is often caused through the use of man-made installations. The ENMOD Convention requires that environmental modification techniques use natural forces from the environment as weapons to war.

The lack of clarity of grammar in the ENMOD Convention caused a lot of criticism in 1991 against the backdrop of Iraq's actions in the Gulf War. One of them states that the ENMOD Convention focuses only on 'science fiction' techniques in nature and ignores the damage caused by conventional warfare methods. Despite this, proposals to revise the text were not adopted at the Review Conference in 1992. ${ }^{91}$

Thus, Iraq does not meet the criteria for environmental damage in both Articles 35 (3) and Article 55 (1) of Additional Protocol I and the ENMOD Convention because of the 'long-term' element in Additional Protocol I and the manipulation of natural processes in the ENMOD Convention is not met. Furthermore, Iraq is not a party to either instrument and does not reflect customary international law. ${ }^{92}$
Karen Hulme, Op.Cit., p. 68.

Yoram Dinstein, Loc.Cit.

Karen Hulme, Loc.Cit.
Katherine M. Kelly, Op.Cit., p. 948.

Yoram Dinstein, Op.Cit., p. 195.

Ibid., p. 193. 


\section{E. IRAQ'S \\ INTERNATIONAL \\ RESPONSIBILITY FOR THE OIL SPILLS AND BURNS IN THE GULF WAR}

In the Advisory Opinion on Nuclear Weapon Case, ICJ has confirmed that the state's obligation not to damage the environment is an international customary law. ${ }^{93}$ This shows that Iraq has violated customary international law and the consequences for a form of international responsibility. However, in international law, law enforcement is a complex issue. ${ }^{94}$ Liability under international environmental law only provides for a civil liability system, whether it is contained in the treaty itself or referring to the customary law of state responsibility.

The state's obligations which are also the basis for state responsibility towards the environment, among others, are contained in the Principle 21 of the Stockholm Declaration which applies both during times of war and times of peace. ${ }^{95}$ The ICRC, in its 1992 report to the UN General Assembly on environmental protection in times of armed conflict, said: ${ }^{96}$

"in addition to the rules of law pertaining to warfare, general (peacetime) provisions on the protection of the environment may continue to be applicable. This holds true in particular for the relations between a belligerent State and third States."

The weaknesses of Additional Protocol I and the ENMOD Convention left big questions after the Gulf War about who is responsible for cleaning up environmental damage. Despite an inability to blame Iraq for violating the treaty related to environmental damage during the war, the US and the international community,

93 UNEP, Protecting the Environment During Armed Conflict, Op.Cit., p. 25.

94 Karen Hulme, Op.Cit., p. 72.

95 See Principle 21 of the Stockholm Declaration.

96 Jean-Marie Henckaerts and Louise Doswald-Beck, Customary International Humanitarian Law Volume II: Practice, New York: Cambridge University Press, 2005, p. 870 . through the United Nations, called on Iraq to seek compensatory redress. Iraq has to pay for the international team's services that cleaned up oil spills and extinguished oil well fires. ${ }^{97}$

This is because various organizations are participating in the cleaning effort in the Gulf region. In early March 1991, the United Nations sent a special mission to Kuwait to investigate the damage caused by the war. Many other groups are also researching and trying to help clean up oil in Kuwait. However, the problem that arose is the lack of effort by Saudi Arabia and Kuwait in the clean-up operation. Problem further occurred when the UN was running low on funds to fight oil fires. For this reason, in January 1991, the US Congress also urged Iraq to take action to restore the damaged environment. ${ }^{98}$

The United Nations played a vital role in the Gulf War, with the Security Council at the forefront of dispute resolution. The Security Council is committed to preventing environmental destruction long before fires and oil spills occur. The Security Council first issued this involvement in Resolution No. 670, adopted September 25, 1990, where the Security Council reminded Iraq of its obligations under the 1949 Geneva Conventions. ${ }^{99}$

In Resolution No. 674 of October 29 1990, the Security Council specifies how the 1949 Geneva Conventions bind Iraq. ${ }^{100}$ The resolution also calls on countries to collect data to file charges against Iraq and seek compensation under international law. In Resolution 686 of March 2, 1991, the Security Council called on Iraq to accept its obligations under international law to compensate other countries for losses

\footnotetext{
97 Katherine M. Kelly, Op.Cit., pp. 935-936.

$98 \quad$ Ibid., p. 937.

99 David D. Carson, "The United Nations Compensation Commission for Claims Arising out of the 1991 Gulf War: The Arising Prior to Decision", Journal of Transnational Law \& Policy, Vol. 14, No. 2, 2005, p. 310.

100 Security Council Resolution 674 (1990) [Iraq-Kuwait], 29 October 1990, S/RES/674 (1990).
} 
caused by Kuwait's Iraqi invasion. ${ }^{101}$ However, the Resolution language is not strong enough because it calls on Iraq to accept its obligations based solely on the principle of state responsibility. Therefore, through Resolution 687 of April 3, 1991, the Security Council affirmed Iraq's obligation to pay compensation for the resulting losses, including environmental damage and depletion of natural resources. ${ }^{102}$ To take a step further regarding the compensation process, the Resolution established a funding unit to handle all claims for loss, including environmental claims. This resolution appoints the Secretary-General of the United Nations to develop a structure for funding pending final Security Council approval. Iraq reluctantly accepted the Resolution.

Under Resolution 692, the Security Council established the governing council of the United Nations Compensation Commission (UNCC) and created the Compensation Fund. ${ }^{103}$ The UNCC itself is an administrative body, not a judicial body, whose function is to review and fulfill claims made by the parties concerned for environmental damage and depletion of natural resources caused by Iraq's invasion and occupation of Kuwait. ${ }^{104}$ The commission set standards for determining compensation for parties harmed by Iraq during the Gulf War, as well as developing a scheme to ensure Iraq made the payments required. This plan involves advice from the Secretary-General of the United Nations, as defined in Resolution 687.

The Compensation Fund itself is funded from the presentation of Iraqi revenue through oil exports. Initially, the percentage was $30 \%$ based on Security Council

101 Security Council resolution 686 (1991) [Iraq-Kuwait], 2 March 1991, S/RES/686 (1991).

102 David D. Carson, Op.Cit, p. 312.

103 Security Council resolution 692 (1991) [Iraq-Kuwait], 20 May 1991, S/RES/692 (1991).

104 Jay E. Austin \& Carl E. Bruch, Op.Cit., p. 187.

105 Security Council resolution 705 (1991) [Iraq], 15 August 1991, S/RES/705 (1991)

106 Security Council Resolution 1330 (2000) [on the situation between Iraq and Kuwait], 5 December 2000, S/RES/1330 (2000)
Resolution 705 of $1991^{105}$ and was lowered to $25 \%$ through Resolution 1330 of $2000 .{ }^{106}$ In 2003, Resolution 1483 again decreased the percentage to only $5 \%{ }^{107}$ and was also emphasized through Resolution 1956 in $2010 .^{108}$

Iraq became nearly bankrupt after the end of the Gulf War, and future revenues from Iraqi oil sales are likely to be the best source of its finances. The original plan was that a few percent of the proceeds from the sale of the oil would be used to pay compensation for the damage caused by Iraq. ${ }^{109}$ However, since the regime in power in Iraq is still in power and economic sanctions have been continuing for longer than expected, a scheme was introduced in 1995 that allowed Iraq to sell oil on world markets under an "oil for food program" plan. This plan is basically to enable Iraq to sell oil, while the United Nations will receive the revenue from the sale, and Iraq is allowed to bring the proceeds from the sale of oil only in the form of food and medicine. This is stated in Security Council Resolution 986 of April 14, 1995. ${ }^{110}$

The legality of Security Council Resolution No. 687 is indisputable, despite the consideration that: (1) Iraq is not a party to Additional Protocol 1 or the ENMOD Convention; (2) The ENMOD Convention and the environmental protection provisions in Additional Protocol I do not constitute customary international law, and; (3) even if both instruments were applicable to Iraq, there was no consensus on the legal consequences. Resolution 687 has a binding effect on Iraq, adopted in Chapter 7 of the UN Charter. Concerning its substance, the Resolution bases "unlawful acts that result in the Iraqi state's

107 Security Council resolution 1483 (2003) [on the situation between Iraq and Kuwait], 22 May 2003, S/RES/1483 (2003).

108 Security Council resolution 1956 (2010) [on termination of the arrangements for depositing into the Development Fund for Iraq of proceeds from export sales of petroleum, petroleum products and natural gas], 15 December 2010, S/RES/1956(2010).

109 Katherine M. Kelly, Loc. Cit.

110 Security Council Resolution 986 (1995), 14 April 1995, S/RES/986 (1995). 
responsibility under international law" for environmental damage resulting from the illegal invasion of Kuwait, in violation of the UN Charter and customary international law, rather than the Humanitarian Law. In other words, Iraq's obligation to pay compensation for environmental damage stems from the jus ad bellum offense and not from any possible violation of jus in bello. ${ }^{111}$

Meanwhile, with regard to individual responsibility towards Saddam Hussein was not determined because there was no possible mechanism to bring individuals responsible for war crimes at that time. ${ }^{112}$ In fact, taking individuals accountable has an educational effect on the command and its members about the impact of their actions. ${ }^{113}$ It was not until the end of the Gulf War that an international tribunal for war crimes was established, namely with the International Criminal Court (ICC) establishment through the Rome Statute in 1998, which only functioned in 2002. The Rome Statute, at last, included crimes using the method of war which results in environmental damage with the criteria of 'widespread, long-term and severe'..14 Thus, the problem remains the same: the limits of environmental damage must be lowered. Otherwise, the environment, which is in the interest of all humanity, will continue to be ravaged by wars using increasingly devastating and increasingly sophisticated technological weapons.

\section{F. CONCLUSION}

The discussion has shown that the national legal instruments that can overcome the problem of the impact of war on the environment are fragile, as they even have not been able to address the worst case of environmental damage caused by the Gulf War. At the time of the Gulf War, Article 35 (3) and Article 55 (1) Additional Protocol I

\footnotetext{
111 Yoram Dinstein, Op.Cit., p. 196.

112 Ibid.

113 Ibid.
}

and Article 1 (1) of the ENMOD Convention were not customary international law. In addition, Iraqi measures did not meet the criteria in either instrument because Additional Protocol I required that the "long-term" criteria last for a decade. To address this issue, these two instruments must be recognized by countries as customary international law so that they have binding legal force for all countries. Then, seeing how the Gulf War outcome alone is enough reason to lower the standard of time.

In addition, the ENMOD Convention setting, which requires elements of intention to change natural processes to be included in the category of environmental modification techniques, should also be revised. The ENMOD Convention looks too far ahead to ignore conventional environmental modification techniques, such as herbicides or other man-made installations. Some experts have suggested the creation of the Ecocide Convention or the 5th Geneva Convention which specifically addresses environmental protection in war. However, lowering the standards in Additional Protocol I and providing the explicit language of the ENMOD Convention on environmental modification techniques alone are sufficient to address this problem.

Lastly, the form of Iraqi responsibility for its actions damaging the environment and its neighboring countries falls in the form of compensation. Under Security Council Resolution 687 of 1991, Iraq was held responsible for all loss and damage caused by Kuwait's invasion and occupation, including environmental damage. Through Resolution 692 of 1991, the UN has also established UNCC and UNCF to fund these victims' compensation. However, the use of war methods that resulted in environmental damage was not included in the category of war crimes or

114 See Article 8(2)(b)(iv) of Rome Statute, A/CONF.183/9 of 17 July 1998 (entered into force 1 July 2002). 
serious violations of Geneva Convention IV at that time. As no war crimes occurred, no criminal trials were held after the Gulf War. Seeing this, the authors suggest that the use of war methods that cause environmental damage is categorized as a serious violation in the Rome Statute should be discussed further, especially regarding the standards which are also as challenging to meet as the Additional Protocol I and the ENMOD Convention. This is important because the current environment is of universal interest and similar actions need to be prevented from happening in the future.

\section{REFERENCES}

\section{Books}

Arkin, William M. (et.al), On Impact Modern Warfare and the Environment: A Case Study of the Gulf War, A Greenpeace Study Prepared for a "Fifth Geneva" Convention on the Protection of the Environment in Time of Armed Conflict, London: Greenpeace, 1991.

Cordesman, Anthony H., Kuwait: Recovery And Security After The Gulf War, Colorado: Westview Press, 1997.

Doswald-Beck, Louise, San Remo Manual on International Law Applicable to Armed Conflicts at Sea, Cambridge University Press, Cambridge, 1995.

Edwards, Jonathan P., The Iraqi Oil "Weapon" in the 1991 Gulf War: an International Law Analysis, Monterrey: Naval PostGraduate School, 1992.

French, Laurence A. \& Lidija NikolicNovakovic, War Trauma and its Aftermath: An International Perspective on the Balkan and Gulf Wars, Lanham: University Press of America, 2012.

Henckaerts, Jean-Marie \& Louise DoswaldBeck, Customary International Humanitarian Law Volume II: Practice, New York: Cambridge University Press, 2005.

Hulme, Karen, War Torn Environment: Interpreting the Legal Threshold,
Leiden: Martinus Nijhoff Publishers, 1750.

Jha, U. C., Armed Conflict and Environmental Damage, New Delhi: Vij Books India Pvt Ltd, 2014.

Jr., Earle Rice, Overview of the Persian Gulf War, 1990, Newark: Mitchell Lane Publishers, 2009.

MacDonald, Ronald St. John, Marine Pollution and Spoliation of Natural Resources as War Measures: a Note on Some International Law Problem in the Gulf War, Boston: Martinus Nijhoff Publishers, 1994.

McCoubrey, Hilaire \& Nigel D. White, International Law of Armed Conflict, Aldershot: Dartmouth Publishing Co. Ltd., 1992.

Poonian,Chris, The Effects of the 1991 Gulf War on the Marine and Coastal Environment of the Arabian Gulf: Impact, Recovery and Future Prospects, London: King's College, 2003.

Price, A. R. G. (et.al), The 1991 Gulf War: Environmental Assessment of IUCN and Collaborators, Gland: IUCN, 1994.

Shaw, Malcolm N., International Law: Sixth Edition, Cambridge University Press, New York, 2008.

Starke, J. G., Pengantar Hukum Internasional, Jakarta: Sinar Grafika, 2006.

Wall, Andru E., Legal and Ethical Lessons of NATO's Kosovo Campaign, Newport: Naval War College Press, 2002.

\section{Other Documents}

Beyond Broadcast Curriculum Guide, "Timeline", https://www.pbs.org/wgbh/pages/fr ontline/teach/gulfguide/gwtimeline. html.

Caggiano, Mark J. T., "The Legitimacy of Environmental Destruction in Modern Warfare: Customary Substance Over Conventional Form", Boston College Environmental Affairs Law Review, Vol. 20, No. 3, 1993. 
Callanan, Brian \& David Weiler, "War Budgeting Strategies: Case Studies of The Gulf War and The Iraq War, Briefing Paper No. 39", Harvard Law School Federal Budget Policy Seminar, 2008.

Carson, David D., "The United Nations Compensation Commission for Claims Arising out of the 1991 Gulf War: The Arising Prior to Decision", Journal of Transnational Law \& Policy, Vol. 14, No. 2, 2005.

Evans, Graham, Persian Gulf, Encyclopædia Britannica, 2016, http://www.britannica.com/place/Pe rsian-Gulf.

Green, Leslie C., "The Environment and the Law of Conventional Warfare", Canadian Yearbook of International Law, Vol. 29, 1992.

Gulf War Fast Facts, CNN Library, 2015, http://edition.cnn.com/2013/09/15/ world/meast/gulf-war-fast-facts/.

Handl, "Gunther, Declaration of the United Nations Conference on the Human Environment (Stockholm Declaration) 1972, and the Rio Declaration on Environment and Development 1992", United Nations Audiovisual Library of International Law, 2012.

Hulme, Karen, "Armed Conflict, Wanton Ecological Devastation and Scorched Earth Policies: How the 1990-91 Gulf Conflict Revealed the Inadequacies of the Current Laws to Ensure Effective Protection and Preservation of the Natural Environment", Journal of Conflict and Security Law, Vol. 2, No. 1, 1997.

Legality of the Threat or Use of Nuclear Weapons Case, Advisory Opinion, [1996] I.C.J. Rep. 226.

Lindén, Olof (et.al), "The Environmental Impacts of the Gulf War 1991", Interim Report of International Institute for Applied Systems Analysis, IR-04-019, 2004.

Persian Gulf War, A+E Networks, 2009, http://www.history.com/topics/persi an-gulf-war.
Second Review Conference of the Parties to the Convention on the Prohibition of Military or Any Other Hostile Use of Environmental Modification Techniques, ENMOD/CONF.II/11, 17 September 1992, Attachment.

The Editors of Encyclop/Edia Britannica, "Persian Gulf War 1990-1991", 2015, http://www.britannica.com/event/P ersian-Gulf-War.

Toukan, Abdullah, "The Gulf War and the Environment: the Need for a Treaty Prohibiting Ecological Destruction as a Weapon of War", The Fletcher Forum of World Affairs, Vol. 16, 1991.

Understandings of the Enmod Convention, Report of the Conference of the Committee on Disarmament, Volume I, General Assembly Official records: Thirty-first session, Supplement No. 27 (A/31/27), New York, United Nations, 1976.

United Nations Environment Programme, Protecting the Environment During Armed Conflict: An Inventory and Analysis of International Law, UNEP, Nairobi, 2009.

Wald, Matthew, "After the War: Gulf Oil Spill Vexing Cleanup Efforts", The New York Times, 7 April 1991, http://www.nytimes.com/1991/04/0 7/world/after-the-war-gulf-oil-spillvexing-cleanup-efforts.html.

\section{Legal Documents}

Convention on the Prohibition of Military or Any Other Hostile Use of Environmental Modification Techniques, New York, 10 December 1976, UNGA Res 31/72.

Declaration of the United Nations Conference on the Human Environment Stockholm, 16 June 1972 (A/CONF.48/14 and Corr.1).

Geneva Convention Relative to the Protection of Civilian Persons in Time of War (Fourth Geneva Convention), 12 August 1949, 75 UNTS 287. 
Environment Based on the International Humanitarian Law

Hague Convention (IV) Respecting the Laws and Customs of War on Land, 18 October 1907.

Protocol Additional to the Geneva Conventions of 12 August 1949, and relating to the Protection of Victims of International Armed Conflicts, 8 June 1977.

Report of the ILC on the work of its fortyeight session, $A / 51 / 10$ (1996), 26 July 1996.

Rio Declaration on Environment and Development Rio de Janeiro, 14 June 1992 (A/CONF.151/26/Vol.I).

Rome Statute, A/CONF.183/9 of 17 July 1998 (entered into force 1 July 2002).

Security Council resolution 674 (1990) [IraqKuwait], 29 October 1990, S/RES/674 (1990).

Security Council resolution 705 (1991) [Iraq], 15 August 1991, S/RES/705 (1991).

Security Council resolution 686 (1991) [IraqKuwait], 2 March 1991, S/RES/686 (1991).

Security Council resolution 692 (1991) [IraqKuwait], 20 May 1991, S/RES/692 (1991).

Security Council Resolution 986 (1995), 14 April 1995, S/RES/986 (1995).

Security Council resolution 1330 (2000) [on the situation between Iraq and Kuwait], 5 December 2000, S/RES/1330 (2000).

Security Council resolution 1483 (2003) [on the situation between Iraq and Kuwait], 22 May 2003, S/RES/1483 (2003).

Security Council resolution 1956 (2010) [on termination of the arrangements for depositing into the Development Fund for Iraq of proceeds from export sales of petroleum, petroleum products and natural gas], 15 December 2010, S/RES/1956(2010). 